Instructions for authors, subscriptions and further details:

http://redimat.hipatiapress.com

\title{
The Pedagogical Design Capacity of a Lower Secondary Mathematics Teacher and Her Interaction with Curriculum Resources
}

Ljerka Jukic Matić ${ }^{1}$

1) University of Osijek, Croatia

Date of publication: February $24^{\text {th }}, 2019$

Edition period: February 2019-June 2019

To cite this article: Jukic Matić, Lj. (2019). The pedagogical design capacity of a lower secondary mathematics teacher and her interaction with curriculum resources. REDIMAT - Journal of Research in Mathematics

Education, 8(1), 53-75. doi: 10.4471/redimat.2019.2396

To link this article: http://dx.doi.org/10.4471/redimat.2019.2396

PLEASE SCROLL DOWN FOR ARTICLE

The terms and conditions of use are related to the Open Journal System and to Creative Commons Attribution License (CCAL). 
REDIMAT, Vol. 8 No. 1 February 2019 pp. 53-75

\section{The Pedagogical Design Capacity of a Lower Secondary Mathematics Teacher and Her Interaction with Curriculum Resources}

Ljerka Jukic Matić

University of Osijek

(Received: 16 November 2016; Accepted: 13 November 2018; Published: 24 February 2019)

\section{Abstract}

Various curriculum resources have emerged over the last decades, but the textbook still remains the most used teaching and learning resource in mathematics classrooms. In this paper, we use a case study to analyse the teaching practice of one mathematics teacher. The aim of the study is to examine how the mathematics teacher interacts with the textbook and teacher guide, especially focusing on when the teacher offloads resources from the textbook, adapts resources, or improvises in the classroom. The study was conducted using lesson observations and semistructured interviews. The results showed that the teacher does not favour a particular type of resource mobilization. Her interaction with the given resources can be characterized as a dynamic interplay, where the type of resource mobilization changes from lesson to lesson as well as within lessons. Moreover, the teacher's mobilization of the textbook and the teacher guide depends on the teacher's goals and her assessment of what provides the most pedagogically beneficial instruction for the students.

Keywords: Teacher, interaction with resources, pedagogical design capacity 


\section{Capacidad de Diseño Pedagógico del Docente de Secundaria y su Interacción con los Recursos Curriculares}

\section{Ljerka Jukic Matić}

University of Osijek

(Recibido: 19 Noviembre 2016; Aceptado: 13 Noviembre 2018; Publicado: 24 Febrero 2019)

\section{Resumen}

Varios recursos curriculares aparecieron en las últimas décadas, pero el libro de texto sigue siendo el recurso más empleado para la enseñanza de las matemáticas. En este artículo se presenta un estudio de caso para analizar la práctica docente de una maestra de matemáticas. El objetivo del estudio es examinar cómo la maestra interactúa con los libros de texto y con la "guía del maestro", especialmente cuando utiliza recursos, adaptaciones o improvisaciones en el aula. El estudio se realizó utilizando las lecciones observadas, además de entrevistas semi-estructuradas. Los resultados muestran que la maestra no está a favor de un tipo particular de movilización de recursos. La interacción con los recursos puede caracterizarse como una interacción dinámica. Además, el uso de libros de texto además de la guía para el maestro, depende de las metas educativas del docente, y de la evaluación de qué ofrece los mejores beneficios pedagógicos para la enseñanza de los estudiantes.

Palabras clave: Maestra de matemáticas, interacción con los recursos, capacidad de diseño pedagógico 


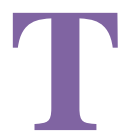

he material artefacts that teachers use to engage in instruction, such as lesson plans, teacher guides, textbooks, and other representations of both content and pedagogy, are collectively referred to as curriculum resources (Brown, 2009; Remillard, 2005). Lately, the research on curriculum resources has shown that curriculum resources are not only limited to material resources (e.g. textbooks, printed teacher guides and other curriculum documents) but also include such things as software, electronic resources and the Internet (Strässer, 2012). According to Pepin, Gueudet \& Trouche (2013), mathematics teaching resources are all resources which are developed and used by teachers or students in their interaction with mathematics in and for teaching and learning, inside and outside the classroom. Adler (2012) introduced a broad conceptualisation of resources in mathematics teaching. Besides material resources, the author also investigates and describes cultural resources and teachers' resources. In this way, it can be considered that teachers and resources interact in a participatory relationship where both the characteristics of the teacher and the characteristics of the resources influence the outcomes in classroom practice (Brown, 2009; Remillard, 2005).

The subject of the utilization of curriculum resources is important in terms of our expectations of what can be accomplished in the classroom. They can promote a teacher's ability to use personal resources to adapt the curriculum materials and to achieve productive and beneficial instructional episodes in the classroom (Ball \& Cohen, 1996; Davis \& Krajcik, 2005; Ahl et al., 2015). Further, curriculum resources can support the teacher's pedagogical content knowledge, help them in the lesson design, suggest tasks, formative assessment and homework and organize individualized teaching, etc. (Davis \& Krajcik, 2005). Using the same curriculum resource, for instance a textbook, two teachers can plan and enact completely different lessons for the same topic. One lesson could be productive and beneficial to students, while the other could be purposeless. Therefore, Brown (2009) refers to teaching as a design process and this ability to design productive classroom instruction he calls pedagogical design capacity.

Among the various existing resources, textbooks are still one of the most used in mathematics education (Fan, Zhu \& Miao, 2013) and heavily influence educational practice (Lepik, Grevholm \& Viholainen, 2015). The 
textbook is usually structured in such a way that it covers the topics that students should encounter during a particular school year, thus the textbook serves as a kind of agreement and support for uniformity within the school system (Johansson, 2006). Textbooks are important for students' learning, but they also affect a teacher's choices in a number of different ways because teachers use them for planning and enacting a lesson (e.g. Pepin \& Haggarty, 2001; Jablonka \& Johansson, 2010). Along with the textbooks, teachers are provided with the accompanying teacher guides, resources designed to support teachers in the planning, implementation and management of instruction. The teacher guides "are available for teachers in their planning process and play an important role in mediating ideas about instruction. They can also contain materials that teachers can use as a basis for their reflections and decisions." (Ahl et al., 2015, p. 181).

There are still many unknowns concerning how teachers design lessons using curriculum resources such as the textbook, and why a curriculum resource is utilized in a particular way (Remillard, 2009). With all the above considerations in mind, we conducted an in-depth study to examine how one mathematics teacher uses the textbook and teacher guide in her teaching practice.

\section{Theoretical Framework}

Pedagogical design capacity (PDC) is a teacher's ability to perceive and mobilize existing resources in order to produce beneficial instructional episodes (Brown, 2009). PDC views teaching as a design activity and considers how teachers use resources to develop classroom instruction that supports their students' learning (Knight-Bardsley \& McNeill, 2016). The resources in PDC include both curriculum resources (physical objects, domain representations, and procedures) and teacher resources (subject matter knowledge, beliefs, and pedagogical content knowledge). How teachers enact the curriculum is influenced by both curriculum resources and teacher resources, therefore this relationship is certainly participatory in nature. Brown (2009) coined the terms offloading, adapting, and improvising to describe different types of interaction that occur between teacher and curriculum resources. Brown (2009) argues that sometimes teachers improvise and design their own instructional episodes, relying mostly on their teacher resources, whereas other times teachers offload their 
agency and directly use curriculum resources, placing the responsibility for guiding instruction directly on the material. Also, teachers adapt curriculum resources to design instructional episodes, i.e. teachers adopt certain components of curriculum resources, but overall they make significant contributions that greatly impact the implementation of lessons.

Brown (2009) states that teachers with high PDC are able to deconstruct curriculum resources, recognize their vital and essential elements, and reconstruct them in order to suit their needs. In other words, PDC represents a skill in perceiving affordances, making decisions, and following through on plans. This ability to perceive and mobilize existing resources can happen both during the lesson planning and lesson enactment. Perceiving can be regarded as a teacher's act of recognizing and interpreting existing resources, evaluating the limitations of the classroom setting, and balancing tradeoffs, while mobilizing emphasizes a teacher's enactment to devise strategies and act on or with the resources (Brown \& Edelson, 2003).

Gueudet, Pepin \& Trouche (2013) point out that, to some extent, a teacher's PDC is dependent on the curriculum resource used and on the ways of working with that resource because each resource has different affordances and constraints. In that manner, Leshota (2015) examined whether a teacher has pedagogical design capacity or not in relation to the textbook. She investigated the mobilization of textbook content, the teacher-textbook relationship, and textbook use. The mobilization of content is examined through the degree of appropriation and opportunities of mediation. The degree of appropriation shows how a teacher offloads, adapts or improvises in the lessons. Opportunities of mediation are examined through injections of mathematical content, omission of mathematical content and mathematical errors. Together, these indicators show the extent to which a teacher's mobilization of the textbook content creates opportunities for mediation in the classroom, and therefore illuminates teachers' PDC (Leshota, 2015). In this framework, Leshota differentiates between two types of injections of mathematical content: robust injections and distractive injections. Robust injections of content are those injections that enhance opportunities for learning mathematics. They point to the teacher's capacity to perceive what the textbook affords and also what the textbook constraints in the teaching practice. Distractive injections are injections of irrelevant content that detract from opportunities of learning. This relates to injections of content that can diverge from the 
common objectives of teaching and learning the topic, and to introduce mathematical errors. Distractive injections display a teacher's lack of PDC. There exists a difference between improvisations of content brought from other sources to lessons and injections of mathematical content. The category of injection of mathematical content deals with the content that was not required by the relevant grade level but which the teacher brought into his/her lessons anyway. Further, Leshota (2015) distinguishes between productive omissions and critical omissions. Productive omissions do not detract from the opportunities of learning. They are best described as leaving out similar worked examples or practice exercises from the textbook when assigning a classroom activity. Critical omissions of content are when content crucial to students' learning of mathematics is left out. They display a teacher's lack of PDC.

To establish the textbook utilization type Leshota (2015) used two categories: deliberate use or tacit use. Deliberate use is intentional, purposeful, conscious utilization, characterized by engaging in long and careful considerations. Tacit textbook use refers to a teacher's textbook use that is not deliberate, characterized by distractive injections and critical omissions. Lastly, the teacher-textbook relationship is determined as either an intimate or non-intimate relationship. An intimate relationship is participatory in nature and does not include critical omissions of content whereas the non-intimate relationship is the opposite.

In our study we will use the analytical framework developed by Leshota (ibid) to examine teacher's relationship with the textbook, utilization of the textbook and consequently teacher's PDC.

\section{Previous Study and Research Questions}

The large-scale study reported in Glasnović Gracin (2011) investigated nearly one thousand Croatian mathematics teachers on the utilization of mathematics textbooks in lower secondary education in Croatia (grades five to eight). The results showed that teachers use textbooks to a great extent for various activities: lesson preparation, teaching a new topic, exercising and assigning homework and that textbooks were used more than other curriculum resources. The results showed a strong reliance on the officially approved textbooks in Croatian mathematics education and indicate that the classroom practice relies considerably on the textbook content and 
structure. This study included a question about the use of teacher guides for planning instruction. Around $23 \%$ of surveyed teachers said they use teacher guides almost always and around $54 \%$ do so often. The results of the study suggest that the textbook is the basic resource for teachers' lesson preparation.

Glasnović Gracin (2011) also analysed the content of Croatian mathematics textbooks, where she identified the predominance of operation activities on the reproductive or simple-connections level with intramathematical content (i.e. symbolic exercises without context). Those results showed that Croatian textbooks place more emphasis on algorithms and the view of mathematics as a tool than as a medium of communication (Heymann, 1996). The Croatian mathematics textbook can be perceived as a "conveyor of the curriculum" (Fan et al., 2013, p. 635) because the requirements of the intended curriculum match the ones in the textbooks (Glasnović Gracin, 2011).

The large-scale study (Glasnović Gracin, 2011) answered the question to what extent textbooks and the accompanying teacher guides are used in Croatian mathematics classrooms. However, it left the question of how and why teachers use the textbooks and teacher guide unanswered. This research aims to partly fill this gap.

In the context of this study, we conceive the teacher guide as a resource consisting mainly of lesson plans, where the number of lesson plans corresponds to the number of hours of mathematics lessons in one school year. The lesson plans list what to use and in what order from the textbook but do not explain the importance of a particular activity, give students' possible misconceptions or suggest how to communicate the main ideas to students. It is also a source of additional activities, which are not included in the textbook. As such, the teacher guide can be thought of as an extension of the textbook.

Therefore we formed following research questions:

1. How does the teacher interact with the textbook (and accompanying teacher guide) in her teaching practice?

2. Does the teacher show an ability to craft productive instructional episodes? 


\section{Methodology}

The study reported in this paper belongs to a case study. Yin (2009) claims that the case study method works when a "how" and "why" question is being asked about a set of events over which the investigator has little or no control A case study research allows the exploration and understanding of complex issues and proves to be helpful when in-depth investigation is required.

\section{Participant}

In this study, we examined the teaching practice of one female mathematics teacher from lower secondary education in Croatia (grades five to eight). For the purposes of this study, we will call the teacher Betty. Betty participated in a previous study where we examined classroom organization and teaching practice among several lower secondary school teachers (Glasnović Gracin \& Jukic Matić, 2016). Consequently, we believe that the teacher did not feel uncomfortable during the study, i.e. during the interview and classroom observations, and we believe that our presence did not cause any change in her usual behaviour in the classroom.

Betty obtained her teaching degree from the department of mathematics. She has 17 years of teaching experience. In recent years she has become active in professional development activities organized by the Teacher Training and Education Agency. Before 2014, she was more passively involved in professional development as a participant, but since 2014 she has been an educator in her region. Betty uses the mathematics textbooks published by Profil. This textbook series is used by more than $65 \%$ of lower secondary students and teachers in Croatia (data retrieved from the Ministry of Education, Science and Sport). Betty has been using the same textbook series for more than 10 years. We believe that Betty, as an experienced and knowledgeable teacher, represents a valuable participant for the study on the utilization of curriculum resources.

\section{Data Collection}

In this study we used qualitative methods in the form of observations and interviews to obtain an in-depth and extensive understanding of the 
researched issues. The teacher was observed multiple times through school year, but we have chosen to analyse 4 consecutive lesson units as we detected pattern of the textbook use.

Table 1.

Questions and outlines for final interview

\section{Impact of the textbook structure on instruction}

Describe how you usually prepare for a mathematics lesson.

Does the textbook, in your opinion, influence the structure of your instruction? (Title, definitions, language, symbols, sequence, didactical approach, worked examples, figures) Give reasons for that.

\section{Use of textbook}

Describe a lesson with teaching new content. Describe a lesson with emphasis on practicing. (Sub-questions: use of textbook and other materials in observed lessons)

Describe how you choose homework activities and from which sources.

\section{Textbook characteristics}

What do you dislike about the textbooks? What do you like and what is helpful in the textbooks? (For topic of rational numbers also)

How do you select the official textbook? (Exercises set, didactical principles, design and color, thickness, figures and pictures, etc.)

\section{Teacher guide characteristics}

How do you use the teacher guide?

How is the the teacher guide organized? Are there explanations for the provided tasks? Does it contain explanations of key ideas, students' misconceptions, etc.?

We did not tell the teacher the exact focus of our observation in order to prevent any change in her usual teaching practice and textbook utilization. In accordance with the research aims, an observational table was designed to capture activities in the classroom at 5 minute intervals. The categories for each time interval were: current activity, teaching strategy, and writing on the blackboard. Under the activity category we made short notes on what the assigned activity was, how long the activity lasted, what students were doing in the classroom. Under the teaching strategy category, we made notes on what the teacher was doing. For instance, dividing students into groups, using structured questioning, pointing out a figure in the textbook, or using PowerPoint presentation. Under the blackboard category, we kept 
notes on everything that was written on the board. Before each lesson took place, we familiarized ourselves with the textbook content for the particular lesson, examined teacher guide suggestions and activities and curriculum standards for grade six and ensured we had a copy of the textbook and teacher guide with us. This helped in making initial data analysis.

In addition to classroom observations, Betty participated in an interview after each lesson. The teacher was asked to explain how she prepared for the observed lesson, what differed in the enacted lesson from her plan and her reasons for using/not using the textbook in the observed lesson. Her responses from the interview were compared with the observation results to get a better understanding of why a particular curriculum resource was used. The final interview had an additional set of open-ended questions and outlines (Table 1). This provided general information on Betty's planning and enacting of a lesson.

\section{Data Analysis}

The first step in data analysis was transcribing the post-lesson interviews. Each segment that was related to curriculum use was coded as either offloading, adapting, or improvising, and we made additional categories of injection/omission of mathematical content and affordances/constraints of the textbook.

The next step was coding observational data, similarly as with the interviews. The pre-coding that was done in the classroom, where we noted whether something was taken from the textbook or not, helped in coding our lesson segments. Segments were coded for: teacher/student activity; content taken from the textbook, inserted from other resources or omitted from the textbook; injection and omission of mathematical content. Then the interview data were merged with the observational data; using the data from the interview helped us to detect what was offloaded from the textbook or teacher guide, adapted from the textbook or teacher guide, or improvised using the teacher's personal resources. This produced a new table for each lesson. Data from the new tables gave information on the extent of the utilization of resources based on a) the degree to which the teacher offloaded, adapted, or improvised; b) the content the teacher inserted into the lesson from other resources; the content from the textbook which the teacher omitted in her lessons; and injection/omission of 
mathematical content the teacher made in the lessons; c) affordances/constraints of the resources. The time allocated to a specific type of interaction that occurred between the teacher and curriculum resources was calculated from the new tables and activities were grouped into one of three categories: offloading, adapting and improvising.

The final interview was coded in a similar way to the shorter ones. Once the codes, themes and patterns were identified, we returned to the observational data to find further evidence and conflicting information. The coding captured how the teacher interacted and understood her use of curriculum resources e.g. the textbook and accompanying teacher guide in lesson preparation, teaching new topics, exercising and reviewing.

\section{Results}

We observed four lessons in Betty's classroom. All lessons were related to the topic rational numbers: introduction of rational numbers (teaching new content and practice); comparing rational numbers (teaching new content); and adding and subtracting rational numbers (teaching new content). Betty offloaded from the textbook, adapted from the textbook and teacher guide, and improvised, but not to the same extent in every lesson. The types of interaction between the teacher and the resources i.e. the textbook and teacher guide for a particular lesson is given in Table 2 .

Table 2.

Types of interaction between teacher and resources (textbook and teacher guide)

\begin{tabular}{|c|c|c|c|}
\hline $\begin{array}{l}\text { Introduction of } \\
\text { rational } \\
\text { numbers } \\
\text { (teaching new } \\
\text { content) }\end{array}$ & $\begin{array}{l}\text { Introduction of } \\
\text { rational numbers } \\
\text { (practice) }\end{array}$ & $\begin{array}{l}\text { Comparison of } \\
\text { rational numbers } \\
\text { (teaching new } \\
\text { content) }\end{array}$ & $\begin{array}{l}\text { Adding and } \\
\text { subtracting } \\
\text { rational numbers } \\
\text { (teaching new } \\
\text { content) }\end{array}$ \\
\hline $\begin{array}{l}\text { Offloading } \\
(0 \%) \\
\text { Adapting }(0 \%) \\
\text { Improvising } \\
(100 \%)\end{array}$ & $\begin{array}{l}\text { Offloading } \\
(10 \%) \\
\text { Adapting (90\%) } \\
\text { Improvising } \\
(0 \%)\end{array}$ & $\begin{array}{l}\text { Offloading }(0 \%) \\
\text { Adapting }(65 \%) \\
\text { Improvising } \\
(35 \%)\end{array}$ & $\begin{array}{l}\text { Offloading } \\
(65 \%) \\
\text { Adapting (10\%) } \\
\text { Improvising } \\
(25 \%)\end{array}$ \\
\hline
\end{tabular}


The proportion of time was calculated for each type of interaction that was identified within the lesson. Based on the dominant type of interaction that occurred between the teacher and the text, the lessons can be characterized as offloading, adapting or improvising. The type of interaction changed between the lessons and within several lessons, which indicates that Betty does not favour any particular type of interaction with the abovementioned curriculum resources.

In table 2 a report in detail on the lessons which can be characterized as improvising, adapting and offloading is presented.

\section{Improvising}

At the beginning of the lesson on the introduction of rational numbers, Betty explained to her students that they will be solving a worksheet for the entire lesson. She advised them to read the text carefully and to ask her if there was something they didn't understand. Betty planned the lesson as students' individual work. She designed a worksheet that guided the students to discover which numbers make the set of rational numbers. The worksheet systematically reviewed all types of numbers that the students had met so far: decimals, fractions and integers and through structured questioning guided the students to find connections between them. The worksheet did not resemble or was not influenced by the tasks from the textbook or from the teacher guide. The students were working on the worksheets for almost the entire lesson while Betty walked around the classroom and monitored what they were doing. No questions were raised during the process. At the end of the lesson, Betty asked the students to exchange worksheets with their neighbour and to check his work. Then Betty gave guidelines for a discussion in pairs: to identify the types of numbers on the worksheet, to describe the relationship between them and to find what the new set of numbers in the worksheet was called. In the end, she discussed these questions with the whole class.

Betty explained how she planned her lesson: first she looked her monthly plan for teaching and curriculum standards. Then she decided on the lesson goals and students' learning outcomes. Afterwards she examined the textbook, teacher guide and other textbooks she possesses to get an idea of how to design her lesson. She noticed that the textbook does not support 
her goal to systemize all number sets students have learned so far. So she decided to create a worksheet that corresponds to her intentions. The idea about discovery learning in this lesson came from professional development. Betty explained that the professional development workshops she attends have an influence on her teaching practice. Recently the workshops had been promoting discovery learning and student-centred classrooms so she wanted to put what she had learnt there into practice. She saw that for some lessons the teacher guide provides ready-made discovery learning worksheets. Since a similar activity for this lesson was not provided in the textbook or in the teacher guide, she designed one herself.

I designed this worksheet myself. I wanted my students to use discovery learning. In the teacher guide, I saw there are activities involving guided discovery, so I used what I know about discovery learning to design this worksheet.

Betty's planned lesson differed from the enacted lesson. The pair discussion component was added during the lesson when she realised that there would be enough time to incorporate elements of cooperative learning. Referring to her lesson design, Betty explained that she uses her own worksheets or creates new activities when she finds the textbook resources lack a mathematical process such as reasoning or connections within mathematical topics:

Sometimes I need more than what is given in the textbook [...] like this worksheet, where we connected all the numbers we had learned so far $[\ldots] \ldots$ And $[\ldots]$ students make their own conclusions.

\section{Adapting}

For the lesson on practicing the concept of rational numbers, Betty prepared a worksheet with an activity that used discovery learning. In this activity the students were supposed to find out whether all fractions can be written in the form of a decimal number. The activity asked students to write given fractions in the form of a decimal number, to factor its denominator into the primes and to answer if denominator has primes 2 and/or 5. When Betty walked around the classroom she noticed that the students were experiencing some problems; they did not know how to divide numbers, so she stopped their work on the worksheets. Betty steered the students into a whole class discussion by writing several tasks with the division of whole 
numbers on the board. She wanted to remind students how to get decimal numbers. Afterwards, the students went back to work on their worksheets. Betty used an overhead projector to project the solution of the worksheets and students compared their results. Using a class discussion, Betty led students to make the conclusion of how the form of a decimal number depends on the primes in the denominator.

When Betty described her planning for this lesson she said that she had not anticipated difficulties with dividing numbers, so she had planned more activities than were observed. She had to deviate from her plan because without adding the review on division, the students would not have been able to finish the given activity. The discovery learning activity was adapted from the teacher guide. However the activity in the teacher guide had more cases to investigate than the activity Betty gave to the students. Betty also added an additional question about primes 2 and/or 5 in the denominator. In the interview, she explained that she had to adapt the material because she knew that the students would not be able to finish the activity suggested in the teacher guide or reach an adequate conclusion on their own. And she concluded that her decision was based on the lesson enacted a year before.

Betty tends to adapt activities from the textbook according to the goal she wants to achieve or to tailor them to better suit students' needs and abilities:

I can't use the ready-made lesson preparation from the book in total or the content from the textbook without thinking about it. There are always some adjustments. It also depends on the class... there are adjustments to be made between levels in the same class.

In the interview, Betty stated that curriculum standards are the most important guide in her planning - yearly, monthly and daily. After she sets her goals for the lesson, she examines the official textbook and teacher guide, and then other existing resources like other textbooks she possesses and internet materials. Therefore her goals and students' learning outcomes seem very important in terms of the utilization of curriculum resources, especially for adapting resources which constitute a significant part of her teaching practice:

I direct and adapt activities and exercises within a particular chapter based on the learning outcomes that have to be achieved. 


\section{Offloading}

At the beginning of the lesson that dealt with the addition of rational numbers, Betty decided to review the comparison of rational numbers and rules for integer addition. For this segment of the lesson she used a whole class discussion writing a task with integers on the board: when two addends have the same signs and when they have opposite signs. As the motivation for the up-coming lesson, she gave a water level problem. This problem also introduced the addition of rational numbers. Betty assigned worked examples from the textbook as individual work. When the examples were completed, the solutions were written on the board. Later Betty assigned practice exercises from the textbook. After some time, the students discussed the solutions of the assigned tasks. At the end of the lesson Betty assigned homework from the textbook.

The teacher's lesson plan matched her enacted lesson. Betty did not offload the entire lesson. She designed the lesson as a mixture of offloading, adapting and improvising, but with offloading dominating the lesson; the short review of previously learnt subject matter was inspired by the teacher guide suggestion to revise addition but without instruction on how to do it; the motivation and teaching of new content through a water level problem was Betty's own idea; the assigned worked examples and practice exercises followed the textbook's sequence. Betty improvised the motivation because she wanted students to connect what they learn with real life and the textbook did not offer such an opportunity. She offloaded the rest of the lesson because she found the textbook content appropriate for this lesson unit; she considered this unit to be simply a short extension of previously learnt subject matter. Her goals for this particular lesson were aligned with those from the textbook.

In the interview, Betty explained that she sometimes offloads entire lessons. In particular she uses the worked examples. She elaborated on why she lets the textbook influence her lessons, specifying that she always considers the students' benefit above all:

The textbook influences my lessons, but only to a certain extent. If I do not agree with it, I tend to change the lesson... But I always consider the students... I want the textbook and their notebooks to contain similar material. I think they will use the textbook for 
revision more if the textbook and the notebook have almost identical stuff... If what we did in lessons differs significantly from the textbook I think fewer students would use it in any way: not for practicing, revision or studying.

\section{Injections and Omission of Mathematical Content}

Betty omitted some worked examples and practice exercises from the textbook in her lesson. A comparison of what was done in the classroom with the omitted content showed that the omissions of content did not detract from opportunities of learning. For instance, Betty omitted an activity for the addition of rational numbers from the textbook, and designed her own. The activity in the textbook was purely symbolic, not connected with real life context, unlike Betty's activity where she used an authentic situation i.e. the rising level of water in the river, and connected it with addition. Therefore we characterized such omissions as productive omissions.

Betty made several injections of content that are not relevant for this grade level according to the national curriculum standards (MZOS, 2006). She introduced the standard notation of rational numbers in the form $a / b$ and mathematical notation for a set of rational numbers $\mathbf{Q}=\{a / b: a \in \mathbf{Z}$, $\mathrm{b} \in \mathbf{N}\}$ Betty also introduced the mathematical symbols for subset $\subseteq$ and superset $\supseteq$ when she lined up sets of numbers the students had learned so far. She also introduced both types of recurring decimal numbers, those with pure and mixed periods, although those types of decimal numbers are part of the grade eight curriculum in the topic of real numbers. However, Betty emphasized that this is a good place for the introduction of these rational numbers, because the students are already discovering the types of decimal numbers in the given activity and therefore this extension is natural. These injections of content enhanced opportunities for learning thus they were characterized as robust injections.

In the interview, Betty explained that she injects some content that is not prescribed by curriculum standards or given in the textbook because she thinks some things that are omitted from the curriculum are not difficult to master, but that they are important for the rest of schooling:

We prepare students for secondary school, too. Students know that they do not have to learn things that are not included in the 
curriculum, but this way they see correct mathematical notation... So they become familiar with the terms and adopt them gradually. So... then they don't have difficulties with the correct terminology at high school.

\section{Affordances and Constraints of the Textbook and Teacher Guide}

Betty is aware of the textbook's deficiencies, that there are a lot of simple routine exercises for the students, mainly symbolic, so she makes use of "other sources to find more challenging tasks for the students". But despite the fact that the textbook is algorithmic oriented (Glasnovic Gracin, 2011), she considers that it also has many affordances. Betty chose this textbook because it appealed to her visually with only a small amount of information on the page, so students do not get bored with the content. She likes the textbook structure, where a written example is followed by a practice exercise of the same type. Betty also appreciates the "explanations of written examples" which "are also good for parents who help their children." On numerous occasions, even when describing her planning for a lesson, Betty mentioned that she cannot use the lesson plans provided in the teacher guide without reflecting on them:

The prepared lessons have too many activities. I can't do everything they [the authors] anticipate in one school hour, especially if the students are required to investigate by themselves.

With reference to the teacher guide, Betty is also aware of its affordances and constraints. She pointed out that it contains a variety of additional material that helps her in her teaching practice. And whilst the teacher guide contains ready-made lesson plans with prescribed procedures, there is no elaboration on the relevance of the suggested activities. Betty noted that there are no suggestions as to what questions to ask students and little emphasis on the "big ideas". She pointed out that the discovery learning activities from the teacher guide are not adequately explained and that without having participated in professional development workshops she would be unable to make proper use of them. The workshops enabled her to see the potential of the activities presented in the teacher guide.

Professional development has greatly influenced my work over the last few years $[\ldots]$ if there are active methods of learning in the textbook or teacher guide, and the teacher has not participated in 
any workshops related to those methods, he won't be using them. The teacher needs to be directed.

\section{Discussion and Conclusion}

In this study we wanted to examine how an experienced teacher interacts with the curriculum resources, especially in terms of improvising, adapting and offloading. Analysis of the obtained data showed a very complex picture with many factors influencing a particular type of interaction.

\section{Interaction with the Textbook and Teacher Guide}

As an experienced teacher Betty uses the textbook and accompanying teacher guide in accordance with the goal she wants to achieve. Her interaction with these resources can be described as a dynamic interplay between her personal beliefs and the characteristics of the resources. Betty constantly assesses the benefits of offloading, adapting and improvising in her teaching, and the long term effects on her students.

Betty offloaded when the intended learning outcomes in the textbook matched her own goals. As an experienced teacher, Betty is aware of the continuity/stability that her students need, therefore she lets the textbook influence her lessons. In a way, the textbook offers security and convenience for teaching and learning (Love \& Pimm, 1996). Because of this, Betty likes to offload the worked examples from the textbook, which students solve themselves in their notebooks. Although it might seems strange that the worked example is given as a task to solve, Betty has identified a pattern in students' utilization of the textbook at home. If what they did in the lesson resembles the content in the textbook, it is more likely that students will use the textbook for studying. Betty adapted activities from the textbook and teacher guide when she estimated that the activities provided do not suit the students' needs. These needs are depending on the class of students she is teaching, and sometimes they vary between class divisions within one generation. Therefore, Betty does not use ready-made material without thinking about the effect this will have on her students. She improvised when the resources lacked some mathematical process such as reasoning, problem solving or connections within mathematical topics or with real life (NCTM, 2000). Since the textbook analysis showed that the textbook contains activities on the reproductive or simple-connections level 
(Glasnović Gracin, 2011), her improvisation is justified from that aspect. But Betty also likes to improvise and make her own materials to put into practice the knowledge she gained in professional development and to deepen her understanding of what she learnt there.

From the analysis of the obtained results it cannot be said that Betty favours one type of interaction with resources. These types interchange in her lessons and during the lesson as well, which shows that her teaching is indeed a design process (Brown, 2009). The dynamic interplay between resources and teacher that we saw in Betty's classroom is only possible when the teacher is familiar with and understands the curriculum requirements, the approved resources she is working with, and the students' abilities and needs. Such understanding is connected with good pedagogical content knowledge i.e. knowledge of content, knowledge of curriculum and knowledge of teaching (An, Kulm and Wu, 2004).

When a teacher estimates that the official resources do not support their goals, the teacher decides to improvise (Brown, 2009). In that case, it is possible that she makes changes which are not aligned with the intent of the textbook (Davis, Beyer, Forbes, and Steven, 2011). On the other hand, when a teacher heavily offloads on the resources, she may lose focus of the curriculum standards and what students actually need to know in mathematics. It is important to understand that neither solely improvising nor offloading imply effective teaching. A thorough understanding what offloading, adapting and improvising represent is important for lesson design. This is important especially for novice teachers who have a limited knowledge base in terms of curriculum, teaching, students and sometimes the mathematical content to be taught.

\section{Pedagogical Design Capacity and Curriculum Resources}

The collected data show that Betty engages in careful considerations as to what to use from the textbook, how and why, thus Betty's utilization of the textbook can be characterized as deliberate and her relationship with the textbook as intimate. When she described the deficiencies of the textbook, she did not talk just about general problems she has with the textbook, but specified what she likes or dislikes about the topics she taught. Betty does not follow the suggestions from the teacher guide blindly and does not let the teacher guide direct her textbook utilization in the classroom, which 
makes her a designer of teaching and not simply a mediator of the content. Betty designs her teaching according to the curriculum standards, goals and student's learning outcomes which corresponds with Wiggins and McTighe's (2005) idea about teaching as design. They claim as a principle of good instructional design, the "backward" planning from student learning goals is a key element of teaching as design.

Observing Betty in action in the classroom, we can conclude that she possesses pedagogical design capacity, at least for the observed topic of rational numbers. We will elaborate on our conclusion. Being aware of the textbook's affordances and constraints enabled Betty to omit activities that are not relevant for learning, to insert activities from the teacher guide, to adapt activities or to simply use the textbook content. Knowing the characteristics of the teacher guide, she was aware of what she can utilize from it for productive classroom instruction. Moreover, Betty's knowledge about the curriculum requirements, not only for one particular grade but for upper secondary school as well, enabled her to inject mathematical content that did not detract from learning, but rather enhanced it. These robust injections point to the teacher's capacity to perceive what the textbook affords and also what it constrains in her practice. Therefore, they are aspects of content which teachers perceive as constraints to her practice, and are therefore indicative of teachers' PDC (Leshota, 2015); a capacity not just to be able to identify the affordances and constraints but to be competent in the use of the materials (Choppin, 2011).

Further, Betty did not stick to her lesson plan entirely. She deviated from its implementation when she saw students struggling or when she detected an opportunity to enhance the lesson. This shows that even the most thought out plans cannot be always carried through. This can result in further adjustments of the mathematical scope and sequence of the lessons. According to Amador (2015), such understandings provide information about the teacher's PDC and provide insight into the extent to which the teacher is relying on curricular resources.

Betty positions herself as an authority on what happens in the classroom; above the textbook and above the teacher guide. The main reason for this authority lies in knowing the abilities of her students and the affordances and constraints of the textbook. According to Davis et al. (2011), knowledge of students and learning goals are two key factors that teachers with high PDC possess. Moreover, it seems that professional development 
increased Betty's awareness of certain characteristics of the official resources and influenced her utilization of those resources. Professional development helps teachers to learn to adapt the materials which they use in their classrooms, and helps them in developing skills to analyse and use curriculum resources which seems to be crucial for the development of PDC (Davis et al., 2011).

We reported observations from four of Betty's lessons. In all those lessons, the students seemed to be accustomed to the particular type of resource utilization. But what if we had witnessed, for instance, students' resistance toward a worksheet with discovery learning and the failure of Betty's lesson? Would that diminish the teacher's PDC? At some point, the teacher has to incorporate new methods of teaching in her practice. To be able to achieve a high level of PDC, firstly, a teacher has to possess good pedagogical knowledge, and secondly they have to be able to put this knowledge into practice; to try out various strategies and methods in teaching, and reflect on how successful a particular activity may have been. This means that improvements can be made for the next time this strategy is used. A high level of PDC certainly comes with experience, but also from trying out new ways of teaching, reflecting on and changing whatever did not work in a particular lesson. So building PDC can be envisioned as kind of iterative process. Betty remarked that it is "constant work on selfimprovement", which she saw as the reason for professional development.

This is in line with learned adaptations from Choppin (2011). The learned adaptations represent the teacher's ability to design adaptations based on knowledge from prior experience. Such adaptations involve an understanding of how curriculum resources can be used to design instruction to achieve particular outcomes. Thus, the teacher's development of PDC is a critical part of their interactions with the curriculum resources.

\section{Limitations of Study and Further Research}

While this work highlights the practice of one teacher, it is important to realise that the findings cannot be generalised to all teachers. The limitation of this study is related to the analytical framework we used, where we investigated omissions and injections of mathematical content into the lessons. It is possible that teachers produce beneficial instructional episodes without injecting mathematical content from other grade levels. Since PDC 
is the ability to perceive and mobilize, it is also important to observe teachers when they prepare mathematics lessons, as well as when they enact them. The first aspect was not included in our study.

However, our study does increase the knowledge base around PDC and provide a basis for continued studies focused on PDC. Future research could investigate multiple cases of how novice and experienced teachers use curriculum resources over a longer time span. And also, how the level of a teacher's expertise can have an influence on the effectiveness of resource utilization in teaching.

\section{References}

Adler, J. (2012). Knowlege resources in and for school mathematics teaching. In G. Gueudet, B. Pepin, \& L. Trouche (Eds.), From Text to 'Lived' Resources: Mathematics Curriculum Materials and Teacher Development. (pp. 3-22). Dordrecht: Springer

Ahl, L., Gunnarsdóttir, G. H., Koljonen, T. \& Pálsdóttir, G. (2015). How teachers interact and use teacher guides in mathematics - cases from Sweden and Iceland. Nordic Studies in Mathematics Education, 20(3-4), 179-197.

Amador, J. (2015). Mathematics Pedagogical Design Capacity from Planning through Teaching. Mathematics Teacher Education and Development, 18(1), 70-86.

An, S., Kulm, G., \& Wu, Z. (2004). The pedagogical content knowledge of middle school, mathematics teachers in China and the U.S., Journal of Mathematics Teacher Education, 7(2), 145-172. doi:

10.1023/B:JMTE.0000021943.35739.1c.

Ball, D. L., \& Cohen, D. K. (1996). Reform by the book: What is: or might be: the role of curriculum materials in teacher learning and instructional reform? Educational researcher, 25(9), 6-14. doi:

10.3102/0013189X025009006.

Brown, M. (2009). The teacher-tool relationship: theorizing the design and use of curriculum materials. In J. T. Remillard, B. A. HerbelEisenmann \& G. M. Lloyd (Eds.), Mathematics Teachers at Work: Connecting Curriculum Materials and Classroom Instruction (pp. 17-36). New York: Routledge. 
Brown, M., \& Edelson, D. (2003). Teaching as design: Can we better understand the ways in which teachers use materials so we can better design materials to support changes in practice? Research Report, Center for Learning Technologies in Urban Schools (Northwestern University). Retrieved from: http://www.letus.org/papers.htm

Choppin, J. (2011). Learned adaptations: Teachers' understanding and use of curriculum resources. Journal of Mathematics Teacher Education, 14(5), 331-353. doi: 10.1007/s10857-011-9170-3.

Davis, E. A., Beyer, C., Forbes, C. T., \& Stevens, S. (2011). Understanding pedagogical design capacity through teachers' narratives. Teaching and Teacher Education, 27(4), 797-810. doi:

10.1016/j.tate.2011.01.005.

Davis, E.A., \& Krajcik, J.S. (2005). Designing educative curriculum materials to promote teacher learning. Educational Researcher, 34(3), 3-14. doi: 10.3102/0013189X034003003.

Fan, L., Zhu, Y. \& Miao, Z. (2013). Textbook research in mathematics education: development status and directions. ZDM-The International Journal on Mathematics Education, 45(5), 633-646. doi: 10.1007/s11858-013-0539-x.

Glasnović Gracin, D. (2011). Requirements in mathematics textbooks and PISA assessment. Unpublished Doctoral dissertation. Klagenfurt: University of Klagenfurt.

Glasnović Gracin, D., \& Jukić Matić, Lj. (2016). The role of mathematics textbooks in lower secondary education in Croatia: An empirical study. The Mathematics Educator, 16(2), 29-56.

Gueudet, G., Pepin, B., \& Trouche, L. (2013). Collective work with resources: an essential dimension for teacher documentation. ZDM: International Journal on Mathematics Education, 45(7), 1003-1016. doi: 10.1007/s11858-013-0527-1.

Heymann, H. W. (1996). Allgemeinbildung und Mathematik. Weinheim: BeltzVerlag.

Jablonka, E. \& Johansson, M. (2010). Using texts and tasks: Swedish studies on mathematics textbooks. In B. Sriraman, C. Bergsten, S. Goodchild, G. Pálsdóttir, B. Dahl \& L. Haapasalo. (Eds.), The First Sourcebook on Nordic Research in Mathematics Education (pp. 363372). Charlotte: Information Age Publishing 
Johansson, M. (2006). Teaching mathematics with textbooks. A classroom and curricular perspective. Unpublished Doctoral dissertation.

Luleå: Luleå University of Technology.

Knight-Bardsley, A. \& McNeill, K.L. (2016). Teachers' Pedagogical Design Capacity for Scientific Argumentation. Science Education, 100(4), 645-672. doi: 10.1002/sce.21222.

Lepik, M., Grevholm, B., \& Viholainen, A. (2015). Using textbooks in the mathematics classroom - the teachers' view. Nordisk matematikkdidaktikk, 20(3-4), 129- 156

Leshota, M. (2015). The Relationship Between Textbook Affordances and Mathematics' Teachers' Pedagogical Design Capacity. Unpublished Doctoral dissertation. University of Witwatersrand, South Africa. Retrieved from http://wiredspace.wits.ac.za/handle/10539/18211

Love, E. \& Pimm, D. (1996). "This is so": a text on texts. In A. J. Bishop, K. Clements, C. Keitel, J. Kilpatrick \& C. Laborde (Eds.), International Handbook of Mathematics Education (Vol. 1, pp. 371409). Dordrecht: Kluwer.

MZOS [Ministarstvo znanosti, obrazovanja i športa Republike Hrvatske] (2006). Nastavni Plan I Program. Zagreb: Ministarstvo znanosti, obrazovanja i športa Republike Hrvatske.

NCTM (2000). Principles and Standards for School Mathematics. Reston, VA: National Council of Teachers of Mathematics.

Pepin, B. \& Haggarty, L. (2001). Mathematics textbooks and their use in English, French and German classrooms: a way to understand teaching and learning cultures. ZDM - The International Journal on Mathematics Education, 33(5), 158-175. doi: 10.1007/BF02656616. Pepin, B., Gueudet, G., \& Trouche, L. (2013). Re-sourcing teachers' work and interactions: a collective perspective on resources, their use and transformation. ZDM-The international Journal on mathematics education, 45(7), 929-943. doi: 10.1007/s11858-013-0534-2.

Remillard, J. T. (2005). Examining key concepts in research on teachers' use of mathematics curricula. Educational research, 75(2), 211-246. doi: 10.3102/00346543075002211.

Remillard, J.T. (2009). Part II commentary: Considering what we know about the relationship between teachers and curriculum materials. In J. T. Remillard, B. A. Herbel-Eisenmann \& G. M. Lloyd (Eds.), 
Mathematics Teachers at Work: Connecting Curriculum Materials and Classroom Instruction (pp. 85-92). New York: Routledge.

Strässer, R.(2012). Foreword. In B. Pepin, L. Trouche \& G. Gueudet (Eds.), From text to "lived" resources: Mathematics Curriculum Materials and Teacher Development (pp. v-vii). Dordrecht: Springer.

Wiggins, G., \& McTighe, J. (2005). Understanding by design (2nd ed.). Alexandria, VA: Association for Supervision and Curriculum Development.

Yin, R. K. (2009). Case Study Research: Design and Methods. Singapore: SAGE Publications.

Ljerka Jukic Matić is assistant professor of mathematics education at the Department of Mathematics, University of Osijek, Croatia.

Contact address: Direct correspondence concerning this article, should be addressed to the author. Postal address: Trg Ljudevita Gaja 6, 31000, Osijek, Croatia. Email: ljukic@ mathos.hr 